\title{
WHO IS HVALBIFF? NAME AND IDENTITY IN W. F. HERMANS'S “BEYOND SLEEP”
}

\author{
KARINA VAN DALEN-OSKAM \\ Huygens Institute for the History of the Netherlands
}

ABSTRACT

One of the functions of names in literary texts is Akzentuierung - Anonymisierung (accentuating - anonymizing) (Debus 2002, 84). By giving a character a certain name, an author can accentuate that name and that character; conversely, by not providing a name where a name could be expected, an author can keep that person anonymous. Both approaches are deviations from 'normality'. This paper proposes that the accentuating and anonymizing function of literary names can be closely linked to the idea of 'foregrounding' as developed in stylistic research. To illustrate this, this paper presents an analysis of the accentuating and anonymizing use of personal names in the novel Beyond Sleep (1966) by Willem Frederik Hermans (1921-1995), one of the most important 20th-century Dutch literary authors. This paper shows that the stylistic application of names that have an accentuating or anonymizing function is key to sustaining the plot of Beyond Sleep.

\section{[1] INTRODUCTION}

Friedhelm Debus (Debus 2002, 74-89) describes several functions of literary names: Identifizierung (identifying), Fiktionalisierung - Illusionierung (helping to create a believable fictional world), Charakterisierung (characterizing), Mythisierung (pointing out the unity of name and bearer) and Akzentuierung - Anonymisierung (accentuating - anonymizing). The focus in this article is on accentuating - anonymizing, because it is perhaps the most important function when one wants to discover more about names and identities - the theme of this volume. The accentuating function, Debus explains, can be implemented through various formal characteristics of a name: unusual sounds, characters (alliteration or certain metrical characteristics), an archaic form of a name, playful contractions or extensions of a name, and so forth. The counterpart of this aspect of names is the 'not knowing' of a name: someone or something does not have a name in a text or is not referred to by name by the characters who appear in the text (Debus 2002, 84-85).

So ergeben sich einerseits Akzentuierung gleichsam positiv-profilierend und andererseits Anonymisierung entsprechend negativ-profilierend 
in funktionaler Sicht als Abweichungen von der Normalität des Namens, von der Grundfunktion der Identifizierung (Debus 2002, 85).

In paraphrase: 'So the two elements combined in this name function can both be seen as deviations from the normality of the name, of the basic identifying function.' Dieter Lamping's earlier description (Lamping 1983, 57-62) of the same name function is more extensive. He points out that the normal situation that is deviated from is not necessarily the normal situation in real life, but that which is suggested to be the intratextual norm (Lamping 1983, 58). So the deviations (the accentuating of a name or the anonymity of a character) are deviations from the suggested normality within the text itself.

Debus's and Lamping's descriptions show a remarkable overlap with the stylistic term 'foregrounding'. Paul Simpson, the author of a well-known stylistics textbook, describes foregrounding as:

... a form of textual patterning which is motivated specifically for literary-aesthetic purposes. Capable of working at any level of language, foregrounding typically involves a stylistic distortion of some sort, either through an aspect of the text which deviates from a linguistic norm or, alternatively, where an aspect of the text is brought to the fore through repetition or parallelism. (Simpson 2004, 50).

Geoffrey N. Leech \& Michael H. Short - the authors of Style in Fiction: A Linguistic Introduction to English Fictional Prose - describe foregrounding as a linguistic surprise that makes the reader conscious of the power of language (Leech \& Short $1981,28)$ and as 'an artistically motivated deviation' that can be either qualitative (a deviation from the linguistic norm) or quantitative (a deviation in frequency) (Leech \& Short 1981, 48).

This article aims to show that the name function Akzentuierung - Anonymisierung (accentuating - anonymizing) plays an important foregrounding role in the Dutch novel Beyond Sleep, which was originally published in 1966 by Willem Frederik Hermans (1921-1995) ${ }^{1}$. An English translation by Ina Rilke appeared in 2006 (Hermans 2006), and a.o. a Norwegian translation by Eva Paasche (Aldri sove mer) in 1992 (Hermans 1992). In the following, the title and the text of the English translation are used. This novel was extremely popular in the decade following its publication and is still a favourite among Dutch readers: in 2002, members of

[1] For my research I made use of the last edition published during Hermans's lifetime (Hermans 1966/1993). In 2010, the novel was published in a scholarly edition prepared by Jan Gielkens and Peter Kegel and published under the auspices of Huygens ING and the Willem Frederik Hermans Instituut in Willem Frederik Hermans, Volledige werken [Complete Works] 3 (Amsterdam: De Bezige Bij / Van Oorschot, 2010). 
the Maatschappij der Nederlandse Letteren (Society of Dutch Literature) ranked Beyond Sleep as the ninth most 'classic' Dutch literary work. ${ }^{2}$

The plot of Beyond Sleep can be summarized as follows. Alfred Issendorf is a young, ambitious geologist starting on his thesis. His father Alfred, a botanist, died young during a scientific expedition in the Swiss mountains. Alfred joins an expedition to Finnmark with three geologists from Norway in search of evidence of meteorites. He is left very confused after meeting several high-placed academics on his way north. One of Alfred's three Norwegian companions (Arne) is a good friend, but he feels rather threatened by the other two. Alfred proves not to be up to the harsh conditions of the landscape of Finnmark and fails to prevent Arne from falling to his death. He returns home a disappointed man, without any of the grand scientific results he had hoped for.

\section{[2] PRESENTING PERSONS: THE LINGUISTIC POINT OF VIEW}

Let us get back to the basics. For a balanced evaluation of the use of names in a literary text, it is helpful to bear in mind the ways in which an author can designate characters in his or her work. We should also keep in mind that what is normal in the 'real' world is not automatically normal in the fictional world (Lamping 1983, 58).

We can distinguish three linguistic ways of designating characters, namely (1) by labelling them with proper nouns; (2) by using appellatives that describe their genders, roles in society, etc.; these descriptions are usually indefinite noun phrases ('A woman', 'A policeman') unless the same persons are still within view of the narrator/reader after their first mention, when they become definite ('THE woman', 'THE policeman'); and (3) by using passive verbal phrases, for example 'my suitcase and rucksack are weighed at the airport' (Hermans 2006, 71) (my italics), which implies that there must be staff at the airport taking care of this weighing. This last linguistic process keeps the designated persons almost invisible to the reader. The second process (use of definite/indefinite appellatives) does show the characters, but they are mostly kept in the background, so to speak. A proper noun, however, draws a character into the foreground and seems to give him or her a definite identity (Gutschmidt 1981, 490).

When persons are kept invisible - kept in the background - or are given a position in the foreground, this situation helps to convey something about the importance of these persons or about the perspective of the novel and/or the emotional situation of the narrator. As Lamping states about those anonymous characters who occur only once or twice in a text, their anonymity represents their function in the text: they are only 'servants', 'passers-by', and are therefore

[2] See the Digitale Bibliotheek der Nederlandse Letteren (dbnl; Digital Library of Dutch Literature) website: http://www.dbnl.nl/letterkunde/enquete/enquete_dbnlmnl_21062002.htm\#14 (Active 28 July 2012). 
not very important in the text. These characters are often people like messengers or taxi drivers (Lamping 1983, 59). This is the type of anonymity that does not clearly have an accentuating function, because it is very much expected, 'natural', in the context of the story (Lamping 1983, 58). The same goes for the following example. Near the end of Beyond Sleep, Alfred alerts the authorities, which recover Arne's body and take it to a hospital. Alfred travels separately to the place where the hospital is located.

Next morning someone from the police comes to see me. (...)

Together we walk to the clinic where his (Arne's) body has been taken.

A DостоR receives me, after which the policeman leaves.

'Are you a relative?' THE DOCTOR asks. (p. 279)

In another context, both the policeman and the doctor could have introduced themselves to Alfred by mentioning their names, or Alfred could have seen their name tags, for instance. But at this point in Beyond Sleep, the narrator (Alfred) does not mention their names. As readers, however, we expect Alfred to be not very alert to his surroundings: he is still in shock as a result of Arne's death. The name and identity of neither the policeman nor the doctor are relevant to him. However, the fact that he meets a policeman or a doctor is relevant. To take this a step further: we as readers would be surprised if Alfred were to remember the name of the policeman or the doctor. It would be a deviation from the intratextual norm were names to occur here. Alfred would mention their names only if he had something strange or significant to relate about them or about the occasion on which he met them. Although the absence of names here cannot be characterized as 'accentuating - anonymizing', it can be described as a stylistic device that helps to depict Alfred's emotional situation at that point in the story.

This last example will be differently experienced by different readers: some will find it a convincing example of deviating anonymizing, while others will feel the situation to be so 'natural' that they will not regard it as a deviation. Some readers may want to link their interpretation to their idea of whether or not the anonymity is a conscious choice of the author. However, this is not relevant for the literary scholar: the text resulting from either conscious or unconscious stylistic choices remains the same, and is the basis for analysis and interpretation. But there are several examples that even the most sceptical reader will regard as instances of the name function of 'accentuating - anonymizing'. These are presented in the following three sections.

[3] NO NAME, NO FAME

For Alfred Issendorf - the young scientist who is the main character and the narrator of the story in Beyond Sleep - names are important. When someone's name 
is known (by the right persons, of course), he or she is a success in life, and scientific success automatically implies social success. This becomes clear on several occasions, and especially when Alfred tells us his recurring thoughts when he browses through a certain book, namely the 'Mallinckrodt memorial volume offered by his students' (p. 128). This book commemorates the famous (fictional) Professor Mallinckrodt, for whom Alfred's father (who was also called Alfred) worked as a young researcher. Together with this professor, Alfred Sr. attended the (fictional) Botanical Conference at Lausanne in July 1947. The book contains a photograph showing all those who attended the conference. On the facing page, a schematic diagram shows the silhouettes of the heads that appear in the photograph, along with numbers corresponding to a list of names.

However, there are two heads without numbers, and consequently without names. One belongs to a girl in the far left of the front row. Some secretary, no doubt, who happened to be there when the portrait was taken. But the other head belongs to my father. Not yet famous enough, I suppose, when he accompanied the great Professor Mallinckrodt to the conference in Lausanne in 1947. (p. 129)

It is not surprising that no name is given to the secretary: she is one of the 'passers-by' so adequately described by Lamping (Lamping 1983, 59). There are several anonymous secretaries (all female) in Beyond Sleep (and all the scientists Alfred meets are male). The anonymity of Alfred's father in the photograph, however, is very pointed and clearly deviates from the presented normal situation in which all silhouettes are clearly intended to contain a number and all persons are intended to be known by their names. Alfred muses that of all the people who possess a copy of the book, he and his mother and sister are the only ones who know the identity of the numberless young man.

Alfred the First, I mutter, sliding the book in amongst the others on the shelf. Usually I glance in the mirror after that. Died young. Before he had the chance fully to develop his talents. (...) Arne and Qvigstad might well become very famous (Mikkelsen strikes me as too dim). One of the pictures we took in Skøganvarre will be published in a book, duly furnished with names and date. My name has got to be there along with the others. It must be. (pp. 129-130)

Alfred explicitly links his father's fate with the fate he fears for himself - and a photograph without his name below it is the grimmest symbol of that fate that he can imagine. 


\section{[4] MISUNDERSTANDING NAMES}

Alfred has a lot of problems with the Norwegian names he encounters during his trip to the north. He repeatedly hears other people pronounce names, but he just cannot make them out clearly or recognize them. This makes him feel very insecure, and sometimes to fear that he is being tricked. An example is when director Oftedahl tells his (anonymous) secretary:

I suggest you give Frøken [unintelligible] a ring in Oslo, ask her to take a look in the catalogue so she can give you the numbers of the Finnmark photographs, then you will know which box they are in. (p. 54)

The same thing happens when Alfred listens to a conversation between his three Norwegian colleagues in the middle of Finnmark:

'That reminds me, I ran into [unintelligible] the other day. Just back from India, for some United Nations welfare programme, I believe. (...)'

'What did [unintelligible] say to that?' (p. 185)

Alfred emphasizes his problem with Norwegian names when he reaches Ravnastua after finding Arne's dead body. He meets a scientist who is stationed in Ravnastua and who informs the authorities about Arne's fatal accident.

I didn't catch his name, of course, and keep wanting to ask him what it is, but don't get round to it. He's a biologist and mycological expert working for the Natural History Museum in Tromsø. (p. 276)

After all Alfred has gone through, he seems to no longer bother so much about this. This explicit remark emphasizes Alfred's problem understanding Norwegian names. Especially the word 'unintelligible' in the earlier quotes presented above highlights this - accentuating the anonymity of these characters only for poor Alfred. His feelings of insecurity are pointedly sketched by foregrounding the fact that these names are unintelligible to his Dutch ears.

\section{[5] HVALBIF F}

Ironically, there is one Norwegian name that Alfred does hear and reproduce exactly as it is meant to be - but even this leads him into a web of uncertainties. His professor in Amsterdam, Sibbelee, had written to his old mentor Professor Nummedal asking whether Alfred could collect from Nummedal the aerial photographs of Finnmark that he needs. The Norwegian professor had replied, giving the date on which Alfred would be welcome to visit him at the University of Oslo. 
During the visit, Nummedal is not forthcoming about the photographs and Alfred has to explicitly ask for them. Nummedal states that he does not have the photographs and refers Alfred to the Geological Survey in Trondheim.

If you want aerial photographs, you must go and get them from the Geological Survey in Trondheim, which is where they are kept. It is on your way up north, anyway. Pay a visit to the Geological Survey! Østmarkneset, Trondheim. Direktør Hvalbiff! He will be pleased to see you. (...) Hvalbiff is your man. I will telephone at once and tell him to expect you. (p. 27)

Alfred acts on Nummedal's advice. He travels to Trondheim and takes a taxi to the Geological Survey's new building. As he enters it:

A figure emerges from a laboratory filled with throbbing machines. He comes towards me, smiling. He has white wavy hair and wears a bow tie. I give him a meaningful look, thinking he must be Direktør Hvalbiff in person.

'I'd like to speak to Direktør Hvalbiff, if I may,' I say.

All innocence.

And I am innocent.

'Direktør Hvalbiff? He is not in today. I am Direktør Oftedahl, of the Statens Råhstoff laboratory.'

'Isn't the Norwegian Geological Survey in this building?'

'Not in its entirety, or rather not yet. But maybe I can help you. Come with me.' (p. 47)

Alfred explains the purpose of his visit and Oftedahl replies that Professor Nummedal did not call. He tells Alfred:

'They don't know anything about a phone call. Direktør Hvalbiff was here briefly yesterday, then went straight back to Oslo. We are in the process of moving, you understand, and most of the property of the Geological Survey is still in Oslo.' (p. 48)

A few minutes later, oftedahl explains:

'Direktør Hvalbiff and Nummedal do not see eye to eye. It is probably just as well Hvalbiff is not here to receive you. Because if he were here I doubt he would have given you the photographs you want, even if he knew where to find them.' (p. 52) 
Because of the missing index to the aerial photographs that are available, Alfred fails to obtain the ones he needs. During the next stage of his trip, he arrives in Alta and meets his Norwegian colleague and friend, Arne Jordal. Alfred tells Arne about his trip to Trondheim:

'I could have got here two days ago,' I tell him, 'if I had travelled straight here from Oslo. But I went to see Nummedal, and Nummedal said I should call at the Geological Survey in Trondheim on the way.' 'Who did you talk to over there? Was it [unintelligible]?'

'Hvalbiff wasn't there.'

'[Unintelligible] is Nummedal's sworn enemy.' (pp. 78-79)

Here, the foregrounding of the unintelligibility of the name as described in section [4] is key to the interpretation of the whole novel. This is where all the confusion could have been cleared up by the author had Alfred heard all of Arne's words correctly. Later, when Alfred and Arne are travelling through Finnmark with Qvigstad and Mikkelsen, Alfred sees Mikkelsen using the sought-for aerial photographs. He asks Mikkelsen:

'Where did you get them?'

'Nummedal gave them to me.'

'Did Nummedal have any others besides these? More copies, I mean?'

'I don't know. These are from Hvalbiff's institute. Nummedal borrowed them from Hvalbiff.'

'When was that?'

'I don't know.' (p. 192)

Alfred tells Arne about this and reminds him of the visit he made to Trondheim. Arne seems to have forgotten that Alfred told him about Hvalbiff and oftedahl. Arne:

'Oftedahl? I don't remember. And the director's name was Hvalbiff, you say? Strange, that is not a Norwegian name.'

'Yes, Hvalbiff. But Hvalbiff wasn't there.'

'Shame you missed him,' Qvigstad says. 'He sounds good enough to eat.'

'Oh,' I say dully. 'I didn't know Mr Qvigstad went in for cannibal humour. But that's what the name sounded like to me.'

'Hvalbiff means whale meat,' Arne explains.

(...)

'Hvalbiff, or however you pronounce it, wasn't there,' I tell them. 'I ran into a geophysicist by the name of oftedahl. He knew nothing 
about the photographs, but he did know who I meant when I said I was looking for Direktør Hvalbiff.'

'Oh, come on now,' Qvigstad says. 'But let's sit down, shall we?'

He sounds concerned. (p. 197)

After Arne's death and Alfred's return to civilization, Alfred visits Nummedal again. As he leaves Nummedal's house, Alfred has an epiphany. It has taken him a lot of time and a lot of fretting to get to that point, but he has finally got there: he is certain he heard the name Hvalbiff correctly when Nummedal mentioned it.

Hvalbiff, was what Nummedal said. No doubt about it.

Nummedal hates the man. Blind hatred - surprise, surprise.

Damn! It could just be a nickname Nummedal invented for the director of the Geological Survey. How they must have laughed behind my back ... Hvalbiff. That means whale meat, Arne had said. Funny eh, Qvigstad had said, not a trace of fat in it, just like beef.

Like a crash of thunder, it comes to me: the pink, fleshy face of the man I spoke to in Trondheim and who, when I asked for Direktør Hvalbiff, introduced himself as a geophysicist by the name of Direktør Oftedahl.

Could 'Hvalbiff' and Oftedahl be one and the same person?

I am not going to bother to find out. (p. 291).

Thus, he has finally formulated the hypothesis that Hvalbiff is the nickname that Professor Nummedal hatefully bestowed on Director Oftedahl. He is still not absolutely certain of it, though. And, of course, the unintelligible name in Alfred's first discussion with Arne is key to this uncertainty for both Alfred and the poor reader of his story:

'[Unintelligible] is Nummedal's sworn enemy.' (p. 79)

From the first stop on his trip to the north (in Oslo with Professor Nummedal) until almost the end of it, Alfred suspects that he is being tricked by his Norwegian colleagues, and especially by Professor Nummedal. Each time he thinks badly of the professor, he counters his own suspicion with disbelief: he just cannot believe that a respected scientist like Nummedal would deprive a student of one of his old students of the aerial photographs that are necessary for his scientific expedition, even if he thinks that the student's ideas about meteors in Finnmark are stupid. But this really seems to be the case. Or (and this appears to be another of Alfred's thoughts), Nummedal is just a pitiful old man who did not do it on purpose. Alfred's thoughts keep wavering, turning this way and that, continually revolving. This special case of mistaken identity spans the entire novel, expressing all the 
uncertainties and insecurities that Alfred suffers throughout his Finnmark expedition.

As stated, even the reader never gets the complete picture. What role did Oftedahl play? Let us look again at some of the things Oftedahl said to Alfred when he was in Trondheim:

'Direktør Hvalbiff? He is not in today.' (p. 47)

'Direktør Hvalbiff was here briefly yesterday, then went straight back to Oslo.' (p. 48)

'Direktør Hvalbiff and Nummedal do not see eye to eye. It is probably just as well Hvalbiff is not here to receive you. Because if he were here I doubt he would have given you the photographs you want, even if he knew where to find them.' (p. 52)

Especially this last sentence is tantalizing. Is Oftedahl simply being very kind to and protective of the foreign student Alfred? This interpretation is perhaps confirmed by a remark Alfred makes near the end of his conversation with oftedahl. In Dutch, it reads:

Weet $u$ wat dit is? zegt Oftedahl en het lijkt of hij helemaal niet meer beseft waarvoor ik gekomen ben. Hij gaat college geven. Hij neemt mij in bescherming tegen mijn eigen onwetendheid. (Hermans 1966/1993, 52-53)

Which can be translated as:

'Do you know what this is?' Oftedahl says, as though he's completely forgotten what I'm here for. He acts like someone teaching a class. He protects me from my own lack of knowledge. (my italics)

The italicized sentences are subtly adequate when we remind ourselves that Alfred is probably making an enormous blunder by calling Director Oftedahl 'Whale meat' to his face. The sentences, however, are translated differently by Ina Rilke: "Do you know what this is?' Oftedahl says, as if he's forgotten completely what I'm here for. Instead, he launches into an enlightenment session for my benefit' (Hermans 2006, 54). Rilke would perhaps have translated this sentence differently had she possessed the onomastic knowledge presented above.

At the same time, however, Oftedahl's statement on page 52 might suggest that he did know where to find the aerial photographs and had decided not to help Alfred in order to thwart his enemy Nummedal. But then the reader might think that it would be very strange for Mikkelsen to have photographs that Hvalbiff lent to Nummedal, as Mikkelsen clearly states (p. 192). We will never be certain about 
this; the insecurity will never be resolved either for Alfred or for the reader and the literary scholar. But we onomasticians have definitely gained a better understanding of how Willem Frederik Hermans consciously, or perhaps unconsciously created this feeling of insecurity for his narrator and his readers by making very subtle and efficient use of the accentuating and anonymizing function of names.

\section{[6] CONCLUSIONS}

A literary onomastic analysis of the novel Beyond Sleep reveals several cases of Akzentuierung - Anonymisierung as name function. According to Debus and Lamping, the accentuating part of the function could be implemented by sounds, formal deviations, alliteration or certain metrical characteristics, an archaic form of a name, and so forth. In Beyond Sleep the actual device is the fact, explicitly mentioned by the character Arne, that Hvalbiff is not a normal Norwegian surname. The anonymizing counterpart of the name function - when someone or something does not have a name in the text or is not referred to by name by the characters in the text - is implemented in three ways. First, only the name of a secretary and that of Alfred's father are absent from the list of names linking those who attended the congress to their pictures in the photograph in the memorial volume for Professor Mallinckrodt. Second, several Norwegian names are repeatedly [unintelligible] to the young Dutch scientist Alfred. And third, the fact that Hvalbiff is probably a nickname is revealed only gradually during the story and is never confirmed.

As stated in the introduction to this article, the stylistic term foregrounding involves 'a stylistic distortion of some sort, either through an aspect of the text which deviates from a linguistic norm or, alternatively, where an aspect of the text is brought to the fore through repetition or parallelism' (Simpson 2004, 50). In the names in Beyond Sleep, these characteristics of foregrounding are conspicuous in several ways, that is, because (1) Hvalbiff is not a normal Norwegian name; (2) Alfred's father is not referred to by name in the memorial volume; (3) the Norwegian names are repeatedly [unintelligible]; (4) the fact that Hvalbiff is a nickname is only gradually revealed; and (5) the name Hvalbiff/oftedahl is unintelligible to Alfred exactly at the key moment, and there is no certainty for the reader about the identification of Hvalbiff/oftedahl.

Foregrounding is also described as 'a linguistic surprise' that makes the reader conscious of the power of language - and Hvalbiff is a surprise in more ways than one. Finally, foregrounding as an 'artistically motivated deviation' that can be qualitative (a deviation from the linguistic norm) or quantitative (a deviation in frequency) is implemented by the explicitly stated fact that Hvalbiff is not a normal Norwegian surname and that the Norwegian names are repeatedly [unintelligible] to Alfred. 
There is much more to tell about the usage and functions of names in Beyond Sleep (Van Dalen-Oskam 2009). In this article, however, I focused on the most important name function in the novel, as it is closely related to the topic 'name and identity'. Based on sections 3-5 of this article, we can conclude that in this novel, names in their accentuating - anonymizing function are subtle stylistic foregrounding elements used by the author to structure the text and to efficiently build the plot. The fact that Alfred does not understand names either phonologically or semantically defines his identity in that it is an important stylistic tool emphasizing Alfred's feeling of being a victim of scientific powers that are way beyond him and visualizing how Alfred feels hindered in making his scientific name and thus becoming a social success.

The observation that in Beyond Sleep the accentuating - anonymizing name function seems to be identical to 'foregrounding' as used in stylistics, may be helpful in further literary onomastic research, which in my opinion should look at names and their usage and function as powerful stylistic elements.

\section{REFERENCES}

Debus, F. 2002. Namen in literarischen Werken. (Er-)Findung - Form - Funktion. [Names in literary texts. Invention - form - function.]. Stuttgart: Franz Steiner Verlag, Akademie der Wissenschaften und der Literatur, Abhandlungen der geistes- und sozialwissenschaftlichen Klasse. Jahrgang 2002, nr. 2.

Gutschmidt, K. 1981. Aspekte der poetischen Onomastik. [Aspects of poetic onomastics.]. In Proceedings of thirteenth International Congress of Onomastic Sciences, Cracow, 21-25 August 1978, vol. 1, 489-494. Wroclaw etc.

Hermans, W.F. 1966/1993. Nooit meer slapen. Amsterdam: De bezige bij. First ed. 1966, 23rd ed., February 1993.

Hermans, W.F. 1992. Aldri sove mer. Oslo: Gyldendal Norsk Forlag. Oversatt fra nederlandsk og med et etterord av Eva Paasche.

Hermans, W.F. 2006. Beyond Sleep. London: Harvill Secker. Translated from the Dutch by Ina Rilke.

Lamping, D. 1983. Der Name in der Erzählung. Zur Poetik des Personennamens. [Names in stories. On the poetics of personal names.]. Bonn: Bouvier Verlag Herbert Grundmann.

Leech, G.N. \& M.H. Short. 1981. Style in fiction. A linguistic introduction to English fictional prose. London and New York: Longman. 1st ed. 1981, transferred to digital printing 2003. English language series 13. 
Simpson, P. 2004. Stylistics. A resource book for students. London and New York: Routledge.

Van Dalen-Oskam, K. 2009. Professor Nummedal is niet alleen. Een analyse van de namen in Willem Frederik Hermans' Nooit meer slapen. [Professor Nummedal is not alone. An analysis of the names in Willem Frederik Hermans's Beyond Sleep.]. In Tijdschrift voor Nederlandse Taal-en Letterkunde [Journal for Dutch Linguistics and Literary Studies], vol. 125 (2009), 419-449.

AUTHOR CONTACT INFORMATION

Karina van Dalen-Oskam

Huygens Institute for the History of the Netherlands

Royal Netherlands Academy of Arts and Sciences

P.O.-Box 90754

NL-2509 LT, The Hague

The Netherlands

karina.van.dalen@huygens.knaw.nl 